\begin{abstract}
We assessed changes in relative abundance of juvenile fish on a natural cobble and boulder reef near Milford, Connecticut, in summer (JuneAugust) during the years 2004-2008 and in 2016. Fish traps, used to sample structure-oriented fish, were soaked for $\sim 24 \mathrm{~h}$ 2-3 times per week. Catch per unit of effort was used as an index of fish abundance and to standardize differences in sampling effort among study years. Juvenile finfish assemblages during 2004 and 2005 differed most in species composition from the assemblage in 2016. Abundance of 2 warmadapted species, the black sea bass (Centropristis striata) and the oyster toadfish (Opsanus tau), was observed to increase over the study period, and numbers of cunner (Tautogolabrus adspersus) and other cold-adapted species declined. Water temperature was a statistically significant predictor of changes in finfish assemblage over the period of this study, explaining $8.6 \%$ of the observed variation in species composition in the data set. A widely documented trend of gradually warming water temperatures from a local, longterm temperature record was consistent with observations from this study of warm-adapted and cold-adapted fish species on a natural rock reef in Long Island Sound.
\end{abstract}

Manuscript submitted 22 February 2020. Manuscript accepted 28 August 2020. Fish. Bull. 118:275-283 (2020).

Online publication date: 11 September 2020. doi: 10.7755/FB.118.3.6

The views and opinions expressed or implied in this article are those of the author (or authors) and do not necessarily reflect the position of the National Marine Fisheries Service, NOAA.

\title{
Temperature-related changes in species composition of juvenile finfish on a rock reef in Long Island Sound
}

\author{
Renee Mercaldo-Allen (contact author) ${ }^{1} \quad$ Shannon Meseck ${ }^{1}$ \\ Paul Clark' \\ Dylan Redman' \\ Yuan Liu, ${ }^{1,2}$ \\ Lisa Milke ${ }^{1}$ \\ Julie M. Rose ${ }^{1}$ \\ Ronald Goldberg ${ }^{1}$ \\ Email address for contact author: renee.mercaldo-allen@noaa.gov \\ 1 Milford Laboratory \\ Northeast Fisheries Science Center \\ National Marine Fisheries Service, NOAA \\ 212 Rogers Avenue \\ Milford, Connecticut 06460 \\ 2 Integrated Statistics \\ 16 Sumner Street \\ Woods Hole, Massachusetts 02543
}

Recent changes in abundance and distribution of finfish and invertebrate species off the coast of the northeastern United States have corresponded with warming of oceanic (e.g., Nye et al., 2009; Rijnsdorp et al., 2009; Walsh et al., 2015; Hare et al., 2016) and estuarine (e.g., Collie et al., 2008; Howell and Auster, 2012; Crosby et al., 2018) waters. Fish assemblages in estuarine environments, such as Long Island Sound (LIS), experience a broad range of water temperatures and may respond to temperature variations more rapidly than species found in deeper offshore waters (Collie et al., 2008). For this reason, estuaries represent sentinel environments for monitoring changes in composition of faunal communities that result from a changing climate. Importantly, environmental variability in coastal estuaries can influence the structure of fish assemblages on a local scale (Chin et al., 2018), but long-term changes related to rising water temperatures may alter the composition of benthic food webs (Rice et al., 2015). Habitat preferences, physiological tolerances, and life stage of fish species, along with the rate and magnitude of environmental change, may determine the response of individual species to changing temperatures.

Natural rock reefs, composed of patches of cobble and boulder, provide habitat for many ecologically and economically important finfish species (Peters and Cross, 1992; Steimle and Zetlin, 2000). Complex seafloor habitat, with physical relief, seabed roughness, biogenic structure, and large sediment grain size, attracts small and juvenile fish (Diaz et al., 2003). Epifaunal growth on cobble and boulders, such as that of seaweeds, sponges, hydroids, and bryozoans, provides camouflage and cryptic shelter that protect vulnerable fish from predation (Auster et al., 1995; Steimle and Zetlin, 2000) and provide a ready food source (Diaz et al., 2003; Scharf et al., 2006). Rock reef environments may be particularly important in the central basin of LIS, where natural structured habitat is sparse and much of the seafloor consists of featureless sand and shell. Cobble and boulders occur in 
discrete patches in this basin and represent a relatively small proportion of the overall seafloor area (Poppe et al., 2000).

High site fidelity on structured seafloor habitat has been reported for shelter-oriented, temperate reef fish species, including the cunner (Tautogolabrus adspersus), tautog (Tautoga onitis), and black sea bass (Centropristis striata) (Olla et al., 1979; Auster ${ }^{1}$; Able et al., 2005; Drohan et al., 2007). Increasing habitat complexity appears to enhance successful settlement and recruitment in young-of-theyear cunner (Tupper and Boutilier, 1997). In addition to seafloor complexity, composition and distribution of juvenile finfish assemblages may be influenced by ecological factors (e.g., inter- and intraspecific competition, recruitment, and predation) and sensitivity or tolerance to variation in environmental characteristics (e.g., temperature and salinity).

Results of analysis of a long-term record of temperatures measured at the Milford Laboratory, NOAA Northeast Fisheries Science Center, in the central basin of LIS indicate a 50-year trend of increasing water temperatures (Rice et al., 2015; $\mathrm{COA}^{2}$ ) that may be influencing the composition of finfish assemblages. To test whether fish populations in LIS are changing in response to rising water temperatures, we conducted a fish trapping study during 6 summers in 2004, 2005, 2006, 2007, 2008, and 2016 to assess species composition of the juvenile finfish assemblage and relative species abundance over a 12 -year period on a rock reef in this same region of coastal Connecticut.

\section{Materials and methods}

\section{Characteristics of study site}

We studied a natural rock reef in a coastal embayment west of Charles Island near Milford, Connecticut, in LIS at approximately $41^{\circ} 11^{\prime} 13.73^{\prime \prime} \mathrm{N}$ and $73^{\circ} 3^{\prime} 48.65^{\prime \prime} \mathrm{W}$ (Fig. 1). The horseshoe-shaped reef covers an area of approximately $0.25 \mathrm{~km}^{2}$, is discontinuous, and varies in rock density and size, with up to $70 \%$ cover of cobble and boulders and vertical relief up to 1-m high. Mean low water on the reef was 3-4 $\mathrm{m}$, with a $2-\mathrm{m}$ tidal range.

Methods for describing seafloor habitat and categorizing sediments are detailed in Mercaldo-Allen et al. (2011), but briefly, rock sizes were classified, by using the Udden-Wentworth grain-size scale (Lewis and McConchie, 1994), as pebbles (4-65 mm), cobble (65-250 mm), or boulders $(250 \mathrm{~mm}-1 \mathrm{~m})$. To describe seafloor topography, we

\footnotetext{
${ }^{1}$ Auster, P. J. 1989. Species profiles: life histories and environmental requirements of coastal fishes and invertebrates (North Atlantic and mid-Atlantic) - tautog and cunner. U.S. Fish Wildl. Serv. Biol. Rep. 82(11.105), U.S. Army Corps Eng., TR EL-82-4, 13 p. [Available from website.]

${ }^{2}$ COA (Coastal Ocean Analytics LLC). 2016. Detecting climate change impacts in Long Island Sound, $134 \mathrm{p}$. Prepared for the U.S. Environmental Protection Agency. Long Island Sound study. EPA grant number LI96144501. NEI job code: 0302-005. Project code: 2013-007. [Available from website.]
}

collected sediments for grain-size analysis with a SmithMcIntyre benthic grab and used observations made by scuba divers and video and still images taken by a seabed observation and sampling system $\left(\mathrm{USGS}^{3}\right)$. Seafloor sediments around reef structure ranged from all silt clay to a mixture of silt clay and sand and contained discontinuous patches of shell hash or pebbles and a fine silt layer. Communities of seaweeds, sponges, hydroids, and bryozoans heavily colonized cobble and boulder habitat.

\section{Trap deployment}

We used traps to sample fish because they are suitable for use on the irregular topography of rock reefs. Trapping provides a means of assessing relative abundance and diversity of species of juvenile fish in complex environments where other sampling options are limited (e.g., Grabowski et al., 2005; Tallman and Forrester, 2007). Fish traps primarily target demersal and epibenthic species, and trap openings and mesh sizes select for specific life stages. For this study, trap openings targeted the juvenile phase. For the deployments in 2004-2006, a commercially available collapsible shrimp and minnow trap $\left(46 \times 23 \times 23 \mathrm{~cm}\right.$; Memphis Net and Twine ${ }^{4}$, Memphis, $\mathrm{TN})$, lined with 2-mm polyethylene mesh, was used, and for deployments in 2007, 2008, and 2016, traps with a similar design and functionality and with similar dimensions were constructed in-house of a sturdier wire frame lined with 3-mm mesh (Fig. 2). Because we targeted juvenile fish at ages of 1 year or older (>9 $\mathrm{mm}$ standard length), the nominal 1-mm difference in mesh size between the traps did not affect retention of this size class in traps. Traps had a single, central chamber and double entries. They were fitted with a flexible, 6.4-cm-diameter ring opening at both entrances, limiting the size of fish that gained entry into a trap. A 5-kg steel plate along the base of each trap provided ballast and stability.

We deployed strings of 3-4 traps evenly across 5 areas of the reef that had dense cobble and boulder structure (Fig. 1). Traps in each string were spaced $7.6 \mathrm{~m}$ apart. Fishing effort during sampling trips consisted of 15 traps deployed in 2004, 30 traps deployed in 2005-2006, 24 traps deployed in 2007-2008, and 20 traps deployed in 2016. We used catch per unit of effort (CPUE) to standardize for differences in number of traps and sampling trips among study years. We calculated CPUE by summing the number of all fish caught in the months of June, July, and August and dividing by the total annual fishing effort (number of traps multiplied by number of sampling trips). We categorized fish as warm or cold adapted on the basis of temperature adaptation groupings of species from a trawl survey conducted by the Connecticut Department of Energy and

\footnotetext{
${ }^{3}$ USGS (U.S. Geological Survey). 2000. Seabed observation and sampling system. U.S. Geological Survey, USGS Fact Sheet FS-142-00, 2 p. [Available from website.]

${ }^{4}$ Mention of trade names or commercial companies is for identification purposes only and does not imply endorsement by the National Marine Fisheries Service, NOAA.
} 


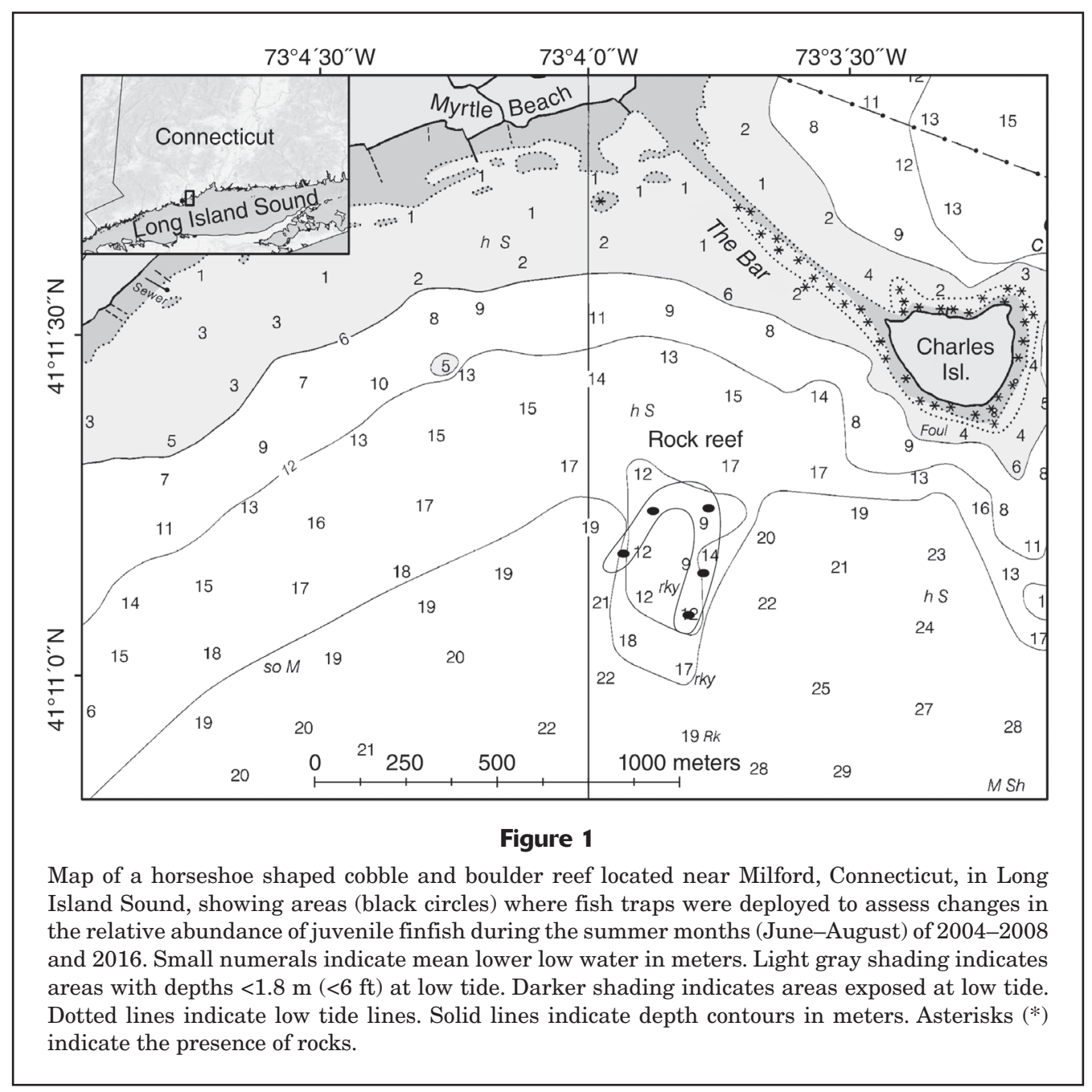

Environment Protection (CT DEEP) in LIS (Howell and Auster, 2012).

Structure-oriented fish have little incentive to leave shelter to enter unbaited traps; therefore, whole fresh northern quahog (Mercenaria mercenaria) were placed in perforated plastic cups inside traps as an attractant. Traps were set or retrieved beginning at the same time daily (0800) and processed in the same sequential order to ensure an approximate 24 -h soak time and reduce the likelihood of predation in the traps. Data from sampling with traps that soaked for a longer or shorter period were not included. Once each trap was retrieved, we inspected it and identified, enumerated, and released all organisms found inside. We conducted sampling trips to deploy traps $2-3 \mathrm{~d} /$ week, from June through August, aboard the Milford Laboratory's 15-m NOAA Ship Victor Loosanoff or a smaller 7-m vessel.

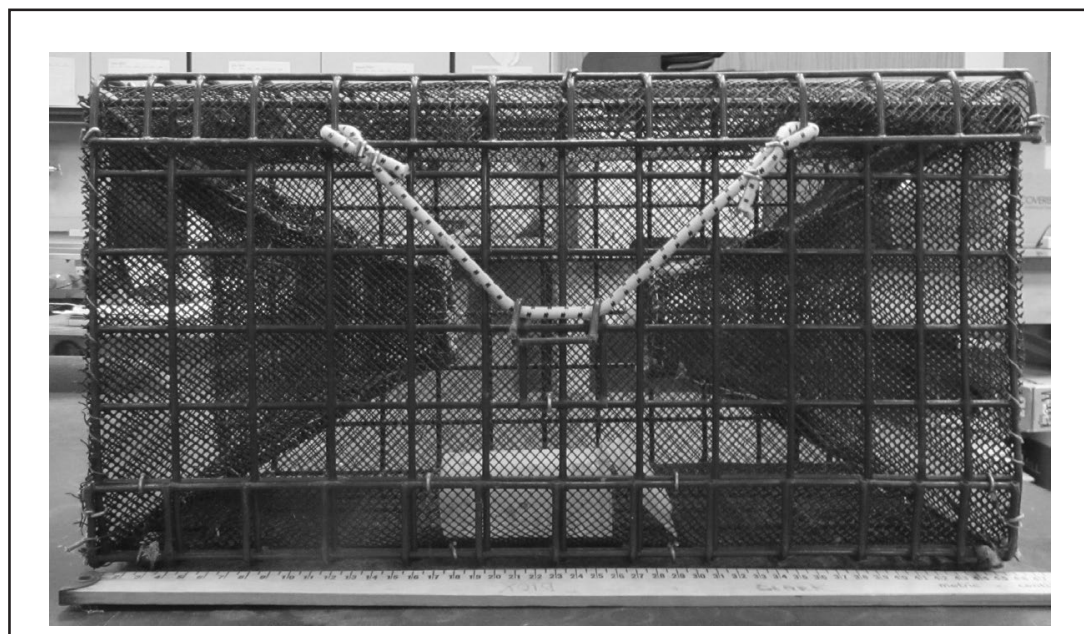

Figure 2

Photograph of the basic style of trap used for sampling of juvenile fish on a cobble and boulder reef in Long Island Sound during the summer months of 2007,2008 , and 2016. Traps were constructed of a wire frame lined with 3-mm mesh. Strings of 3-4 traps were deployed evenly across 5 areas on the reef. 


\section{Water temperatures}

We assessed trends in local summertime temperatures by using a publicly available, long-term historical database maintained by the Milford Laboratory (available from website). Initially, a Bristol thermograph located on a dock in Milford Harbor recorded water temperatures during 1948-1975. From 1976 to the present, including our study period, daily surface temperatures were measured by using thermometer readings of sand-filtered seawater pumped from Milford Harbor. Studies that have analyzed these data have reported increasing water temperatures in LIS over the last 5 decades (see Rice et al., 2015; $\mathrm{COA}^{2}$ ). Because shifts in species distribution and composition of assemblages may occur when summer temperatures approach or exceed tolerance limits, we examined mean water temperatures during June-August, when fish trapping took place and water temperatures were highest, over the 12-year study period.

\section{Statistical analysis}

We analyzed fish assemblage data by using the statistical software program PRIMER, vers. 7 (PRIMER-e Ltd., Auckland, NZ) with the PERMANOVA+ add-on package. The Bray-Curtis coefficient was used to generate a similarity matrix across all pairs of samples. Bray-Curtis is commonly used in multivariate analysis of species assemblage data because it has beneficial properties of coincidence, complementarity, relative invariance, independence of joint absence, localization, and dependence on totals (Clarke et al., 2006). Nonmetric multidimensional scaling was used to visualize similarities in fish assemblage across all samples. The routine in PERMANOVA+ for canonical analysis of principal coordinates was used to identify fish in the benthic assemblage that were associated with each year. We used the Spearman rank correlation to assess the strength of the association between individual species abundance and sampling year. The analysis of similarity (ANOSIM) test in PRIMER was used to test for the significance of differences among fish assemblages for all pairs of years sampled. We used the distance-based linear model routine in PERMANOVA+ to analyze the relationship between the multivariate fish assemblage and local water temperature, by matching daily water temperatures from the Milford Laboratory data set to dates during which fish traps were deployed. We assessed temperature trends by using the robust Theil-Sen regression estimator and a bootstrap method to test significance (Wilcox, 2017). We chose this approach over the classic ordinary leastsquares estimator because of its improved performance under conditions of non-normality or heteroscedasticity.

\section{Results}

Results of ANOSIM of fish assemblages indicate significant differences $(P<0.003)$ between pairs of years of the study period (2004, 2005, 2006, 2007, 2008, and 2016) except between 2004 and 2005 ( $P=0.138$, ANOSIM test statistic $R=0.033$ ) (Table 1 ). Species composition of fish assemblages was most different between 2004 and 2016 $(R=0.923)$ and between 2005 and $2016(R=0.967)$, and pairs of years that were further apart in time generally had greater $R$-values (Table 1 ). The nonmetric multidimensional scaling plot in Figure 3A illustrates differences in assemblages between years. The canonical analysis of principal coordinates also visualizes this overall temporal trend, with greater dissimilarity in fish assemblages between years that were further apart in time (Fig. 3B). Results of Spearman rank correlation analysis (>25\%) indicate that the warm-adapted species black sea bass (coefficient of correlation $[\rho]=0.770$ ) and oyster toadfish (Opsanus tau) $(\rho=0.561)$ were more abundant in 2008 and 2016 than in the other study years and that the cold-adapted species cunner $(\rho=-0.493)$ and grubby (Myoxocephalus aenaeus) ( $\rho=-0.391)$ were more abundant in 2004-2006. The relationship between the fish assemblages and water temperatures was significant, with variation in temperatures explaining $8.6 \%$ of the variation in the fish assemblages $(P=0.0001$, coefficient of determination $\left.\left[r^{2}\right]=0.086\right)$.

Relative abundance, measured as CPUE, was plotted for the most abundant species, including the cunner, black sea bass, oyster toadfish, grubby, rock gunnel (Pholis gunnellus), scup (Stenotomus chrysops), and tautog (Fig. 4). To account for numerical dominance of black sea bass and cunner, we used 2 different y-axes, with values on the first $y$-axis up to 0.60 in the graphs for these 2 dominant species and values on the second y-axis up to 0.06 in

\section{Table 1}

Results of analysis of similarity comparing finfish assemblages on a cobble and boulder reef in Long Island Sound between years: 2004, 2005, 2006, 2007, 2008, and 2016. Differences in assemblages were statistically significant $(P<0.05)$ in all comparisons, except for the difference between 2004 and 2005. $R$ =test statistic from analysis of similarity.

\begin{tabular}{lcc}
\hline Comparison & $R$ & $P$ \\
\hline 2004 vs. 2005 & 0.033 & 0.1380 \\
2004 vs. 2006 & 0.376 & 0.0001 \\
2004 vs. 2007 & 0.141 & 0.0030 \\
2004 vs. 2008 & 0.512 & 0.0001 \\
2004 vs. 2016 & 0.923 & 0.0001 \\
2005 vs. 2006 & 0.386 & 0.0001 \\
2005 vs. 2007 & 0.206 & 0.0006 \\
2005 vs. 2008 & 0.560 & 0.0001 \\
2005 vs. 2016 & 0.967 & 0.0001 \\
2006 vs. 2007 & 0.250 & 0.0001 \\
2006 vs. 2008 & 0.529 & 0.0001 \\
2006 vs. 2016 & 0.781 & 0.0001 \\
2007 vs. 2008 & 0.337 & 0.0001 \\
2007 vs. 2016 & 0.758 & 0.0001 \\
2008 vs. 2016 & 0.280 & 0.0002 \\
\hline
\end{tabular}



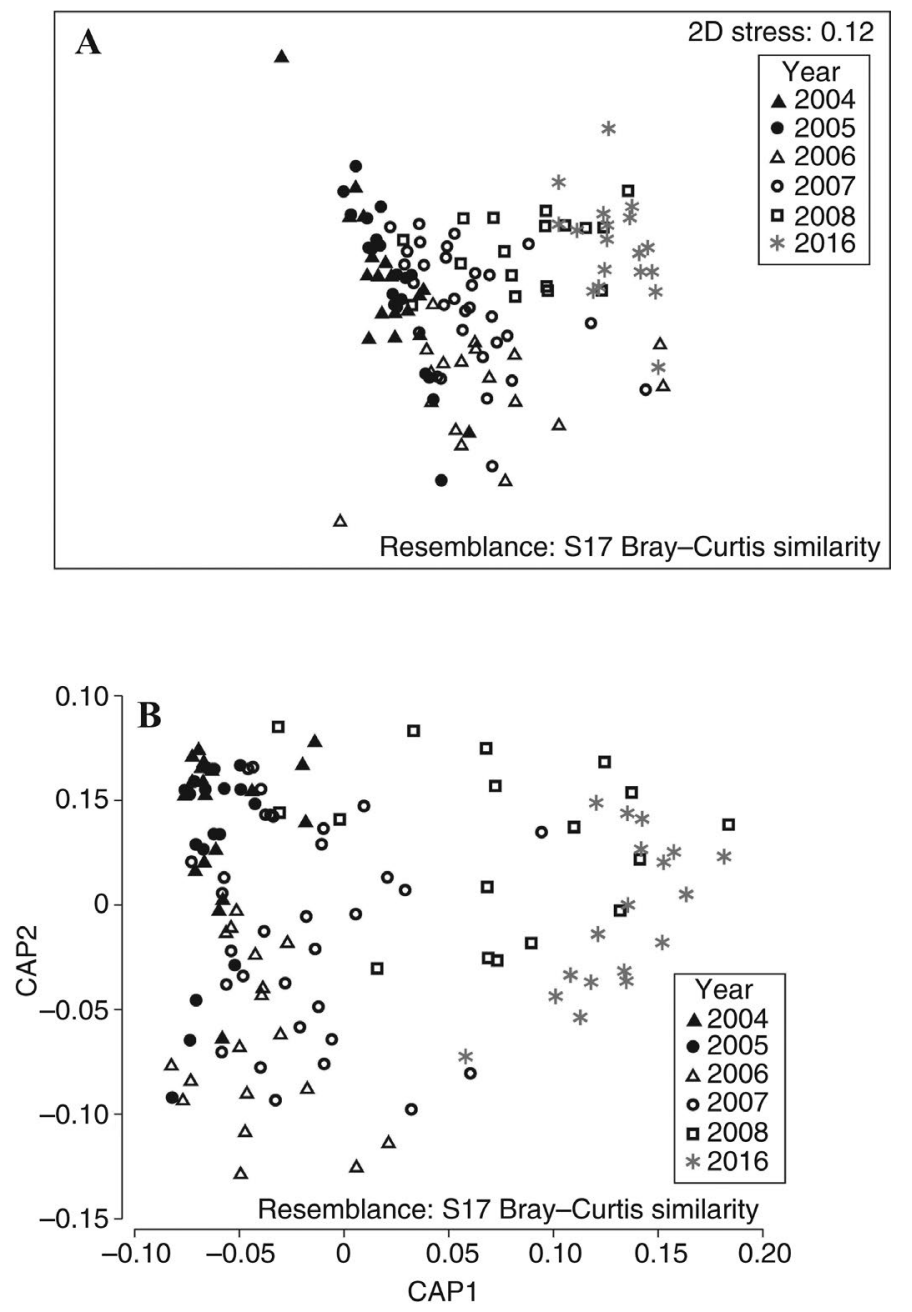

Figure 3

(A) Nonmetric multidimensional scaling plot of finfish community composition and (B) canonical analysis of principal components (CAP) used to visualize monthly patterns in finfish assemblages on a cobble and boulder reef in Long Island Sound during 2004, 2005, 2006, 2007, 2008, and 2016. Data used in the plot and analysis come from sampling with fish traps.

\section{Discussion}

Changes in abundance of individual fish species over the time series indicate an increase in prevalence of warm-adapted species on the reef from 2004 through 2016. Although juvenile black sea bass were not observed in traps during 2004, their numbers rose steadily over the periods of this study with the highest numbers occurring in 2008 and 2016. This trend was also present in data from the CT DEEP trawl survey, with numbers of juvenile and adult black sea bass collected in 2013 greatly exceeding levels observed between 1984 and 2011 (Gottschall and Pacileo ${ }^{5}$ ). In addition, data from a long-term trawl survey (1976-present) conducted by the Millstone Power Station in Niantic, Connecticut, indicate historically elevated catches of juvenile and adult black sea bass since $2013\left(\right.$ DENC $\left.^{6}\right)$. Further, a record high number of young-of-the-year black sea bass was documented in beach seine surveys conducted by CT DEEP at 8 inshore locations during 2015 (Molnar and Howell ${ }^{7}$ ). A similar pattern was observed for juvenile oyster toadfish, although they were not as abundant as black sea bass, with consistently low numbers on the reef during 2004-2007 and higher numbers observed in 2008 and 2016. Overall, numbers of oyster toadfish collected during individual trawl tows are often low because this species prefers rocky substrate where trawling is generally limited (Gottschall and Pacileo ${ }^{5}$; Crosby et al., 2018; DENC ${ }^{6}$ ); hence, fish trapping may be a better means for estimating abundance of oyster toadfish.

In our study, no consistent trends were observed in overall abundance of juvenile tautog and scup on the reef. There was interannual variation in abundance of juvenile tautog collected in fish traps, variation similar to that observed in the data from the CT DEEP trawl survey (Gottschall and Pacileo ${ }^{5}$ ) and near Millstone Power Plant in Niantic $\left(\mathrm{DENC}^{6}\right)$. Scup, which did not appear in traps in 2004, increased in abundance during 2005-2008, with lower numbers observed in graphs for the less abundant fish species. Plots were not produced for the following fish species that were observed in low abundance ( $<4$ individuals) during a single year: winter flounder (Pseudopleuronectes americanus) in 2004, Atlantic tomcod (Microgadus tomcod) in 2005, northern pipefish (Syngnathus fuscus) in 2006, feather blenny (Hypsoblennius hentz) in 2008, spotted hake (Urophycis regia) in 2008, and bluefish (Pomatomus saltatrix) in 2016.

Using temperatures from the Milford Laboratory database, we plotted mean summertime water temperatures from 2000 through 2016 in the central basin of LIS (Fig. 5). Results from regression analysis indicate a significant positive trend (slope $=0.09, P=0.01$ ) between year and water temperature over time.
${ }^{5}$ Gottschall, K., and D. Pacileo. 2016. Job 5: marine finfish survey. Long Island Sound trawl survey, 99 p. In A study of marine recreational fisheries in Connecticut. Federal aid in sport fish restoration F15AF00222 (F-54-R-35). Annual performance report, March 1, 2015-February 29, 2016. Conn. Dep. Energy Environ. Prot., Hartford, CT. [Available from website.]

${ }^{6}$ DENC (Dominion Energy Nuclear Connecticut). 2018. Fish ecology studies. In Annual report 2017. Monitoring the marine environment of Long Island Sound at Millstone Power Station, p. 145-14217. DENC, Waterford, CT. [Available from Millstone Environmental Lab, 314 Rope Ferry Rd., Waterford, CT 06385.]

7 Molnar, D., and P. Howell. 2016. Job 8: estuarine seine survey, 22 p. In A study of marine recreational fisheries in Connecticut. Federal aid in sport fish restoration F15AF00222 (F-54-R-35). Annual progress report, March 1, 2015-February 29, 2016. Conn. Dep. Energy Environ. Prot., Hartford, CT. [Available from website.] 


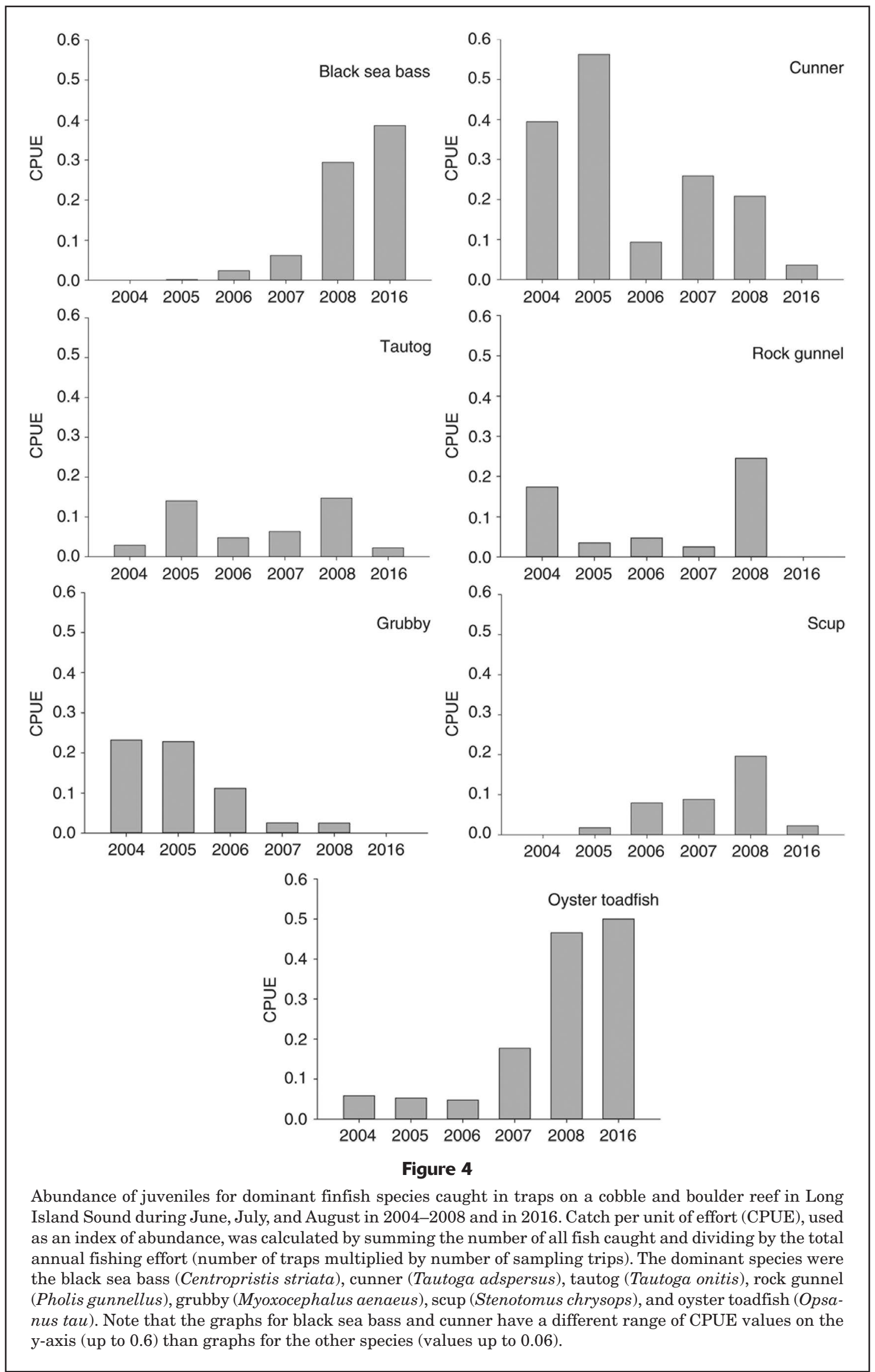




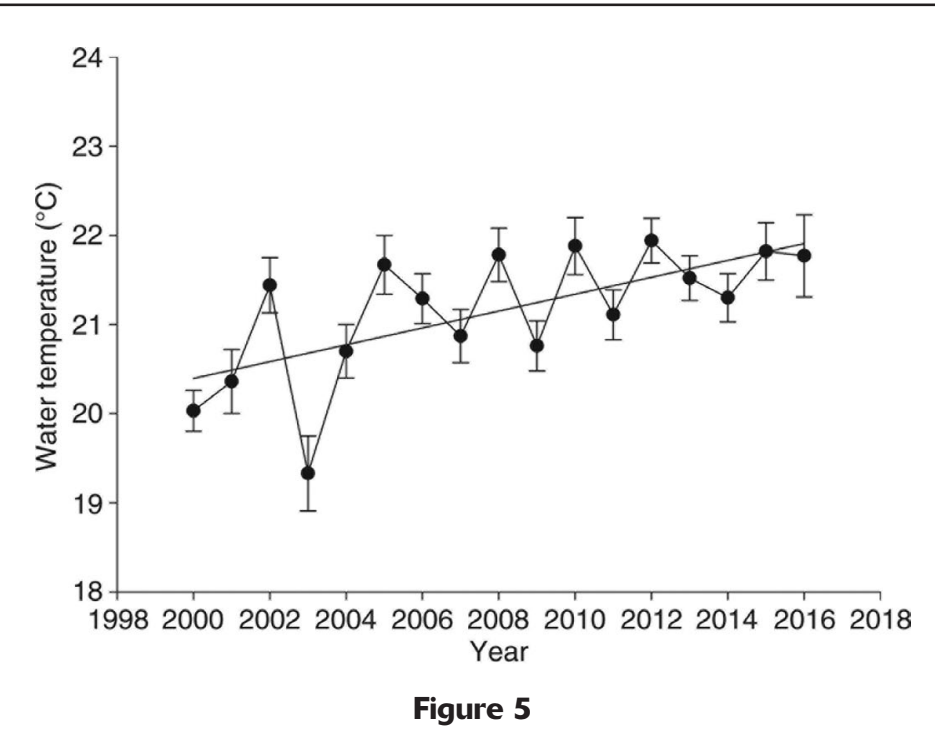

Mean summer (June-August) water temperatures $\left({ }^{\circ} \mathrm{C}\right)$ in the central basin of Long Island Sound at Milford Laboratory, NOAA Northeast Fisheries Science Center, from 2000 through 2016. The regression line illustrates the trend of warming temperatures (slope $=0.09$, $P<0.01$ ), and the error bars indicate standard errors of the mean.

Numbers of grubby on the reef declined from 2004 to 2008, and none were collected during 2016. Similarly, Roseman et al. (2005) noted a reduction in numbers of grubby in the Niantic River and Bay in eastern LIS over an earlier 26-year period (1976-2002), a decline that was attributed to a reduction in eelgrass (Zostera marina) or increased water temperatures. Fewer grubby were caught over time from 1976 to 2016 during the trawl survey at Millstone Power Station in Niantic $\left(\mathrm{DENC}^{6}\right)$. Because grubby also experience low exploitation, changes in their population dynamics could indicate a response to environmental or habitat variability (Roseman et al., 2005). Rock gunnel, most abundant in fish traps in 2008, were also absent from collections at the reef in 2016. In trawl surveys of Norwalk Harbor, Crosby et al. (2018) collected no rock gunnel in bottom-trawl tows after 2009 . Rock gunnel, often found in shallow intertidal waters, have a broad physiological tolerance for variable environmental conditions (Shorty and Gannon, 2013) and are likely to have low sensitivity to warming. These findings indicate that reductions in abundance of rock gunnel may relate to factors other than temperature. Winter

sampling with traps in 2016. Data from the CT DEEP trawl survey indicate a notable increase in abundance of young-of-the-year, juvenile, and adult scup after 1999, followed by interannual variability during subsequent years, which overlap with our study period. Long-term trawl surveys (1974-2016) conducted in eastern LIS also found no discernable trend in abundance of scup over the last 2 decades (Snyder et al., 2019). These findings contrast with those of other studies, which report increased abundance of this warm-adapted species. Elevations over time in the number of scup collected during trawl surveys in Niantic Bay have been reported (DENC ${ }^{6}$ ). Similarly, numbers of scup increased consistently from 1959 to 2005 in a nearby estuary in Rhode Island (Collie et al., 2008).

A progressive decline in abundance of cold-adapted species occurred over the study period. Abundance of cunner, the most numerous species in traps during 2004 and 2005, trended downward, reaching the lowest levels in 2016. Data from both the CT DEEP trawl survey (Gottschall and $\mathrm{Pacileo}^{5}$ ) and from a monitoring program in Norwalk Harbor, Connecticut (Crosby et al., 2018), indicate a longterm decline in abundance of cunner from 1984 to the present. Collie et al. (2008), in a study in Rhode Island, found similar reductions in numbers of cunner over an earlier time frame, from 1959 to 2005 , and suggested that declines in estuarine species with discrete populations, like cunner, could signal a response to climate change. Populations of cunner may be shifting northward (Rose, 2005) or may be stressed by low tolerance to rapidly warming thermal conditions (Crosby et al., 2018). Because cunner are relatively unfished, variations in population size or distribution could relate directly to changes in environmental conditions. flounder, observed in low numbers on the reef in 2004, were not caught in fish traps during 24-h soaks in subsequent years. Observations from long-term studies indicate that abundance of winter flounder in LIS has been on the decline for more than 20 years (e.g., Howell and Auster, 2012; Crosby et al., 2018).

Increases in relative abundance of black sea bass and oyster toadfish on the reef may account for the reductions in the numbers of cunner, grubby, and rock gunnel that we observed. Juvenile black sea bass and oyster toadfish, although opportunistic benthic omnivores, are also voracious predators known to consume young-of-the-year or small-bodied fish (e.g., Sedberry, 1988; Steimle and Zetlin, 2000; Collette and Klein-MacPhee, 2002; Byron and Link, 2010). Young-of-the-year cunner have been found in stomachs of juvenile black sea bass collected in traps (P. Clark, unpubl. data). Highly abundant black sea bass and increasingly numerous oyster toadfish may also be outcompeting these small-bodied species for habitat and resources.

Water temperature was a statistically significant predictor that explained $8.6 \%$ of the observed variation in juvenile finfish assemblages in LIS across our time series. Shifts in the composition of finfish assemblages linked to increased water temperature have been widely reported in southern New England. Benthic cold-adapted species, most notably the winter flounder and American lobster (Homarus americanus), have declined in abundance in LIS (Howell and Auster, 2012; Gottschall and Pacileo ${ }^{5}$; Snyder et al., 2019). A study in Norwalk Harbor conducted during 1987-2016 found changes in demersal fish assemblages related to increased mean water-column temperature (Crosby et al., 2018). Through analysis of the 25-year CT DEEP data set (1984-2008), Howell and Auster (2012) 
discerned a shift in seasonal patterns of abundance of finfish species, from high numbers of cold-adapted (northern) species in spring and warm-adapted (southern) species in autumn to dominance of warm-adapted species during both seasons. In another estuary in southern New England, Collie et al. (2008) observed changes in finfish species composition from 1959 through 2005 that were associated with increased sea-surface temperatures in Narragansett Bay and Rhode Island Sound during spring and summer.

Results from synthesis of temperature data collected from a variety of locations along the Connecticut coastline, including those from the Milford Laboratory historical database, substantiate other indications that summer and winter temperatures in LIS have been rising since 1965 (e.g., Rice et al., 2015; $\mathrm{COA}^{2}$ ). Four decades of data on water temperatures in eastern LIS indicate a rise of $0.45^{\circ} \mathrm{C} /$ decade (Snyder et al., 2019), with an annual mean increase of $0.08^{\circ} \mathrm{C}$ (standard deviation 0.03 ) from 1991 to 2013 (Staniec and Vlahos, 2017). Using the temperature record of the Milford Laboratory, Rice et al. (2015) calculated a warming rate of $0.03^{\circ} \mathrm{C} /$ year for surface waters from 1948 to 2012 in the central basin of LIS. Temperatures in Niantic Bay increased by $0.04^{\circ} \mathrm{C} /$ year from 1976 to 2015 $\left(\mathrm{DENC}^{8}\right)$. Average summer surface temperatures measured by CT DEEP from 1991 to 2016 increased by $1^{\circ} \mathrm{C}$ (Gottschall and Pacileo ${ }^{5}$ ). In studies in Norwalk from 1987 to 2016 , a $1.26^{\circ} \mathrm{C}$ rise in water temperature was observed (Crosby et al., 2018). Subtle increases in water temperature, as slight as $1^{\circ} \mathrm{C}$, can alter abundance and distribution of individual fish species and influence composition of finfish assemblages (Howell and Auster, 2012).

Results of our comparison of juvenile finfish assemblages on a rock reef in LIS, through the use of legacy data from 2004 through 2008 and recent data from 2016, indicate variability in species composition that is consistent with observations from previous studies (e.g., Howell and Auster, 2012; Crosby et al., 2018). We observed a decline in abundance of cunner, a cold-adapted species, and numbers of black sea bass and oyster toadfish, both warm-adapted species, increased steadily. On the local scale of our study at a rock reef near Milford, composition of the fish community differed most between the earliest years of 2004 and 2005 and the most recent year 2016. A widely documented trend of gradually increasing water temperatures may have contributed to changes in species composition and abundance on this discrete cobble and boulder reef in LIS.

\section{Acknowledgments}

We thank R. Alix, A. Allen, E. Bates, G. Fignar, A. Grusky, E. Estela, C. Kuropat, J. Pereira, G. Phillips, J. Reidy, A. M. Salvato, W. Schreiner, G. Sennefelder, L. Vinokur, and

\footnotetext{
${ }^{8}$ DENC (Dominion Energy Nuclear Connecticut). 2018. Winter flounder studies. In Annual report 2017. Monitoring the marine environment of Long Island Sound at Millstone Power Station, p. 111-143. DENC, Waterford, CT. [Available from Millstone Environmental Lab, 314 Rope Ferry Rd., Waterford, CT 06385.]
}

J. Ziskowski for technical assistance. L. Poppe, D. Blackwood, and I. Babb provided video imagery. L. Williams allowed us to place fish traps on his leased shellfish grounds. NOAA dive team members B. Smith, M. Dixon, and D. Veilleux provided underwater photography and habitat assessments.

\section{Literature cited}

Able, K. W., L. S. Hales Jr., and S. M. Hagan. 2005. Movement and growth of juvenile (age 0 and 1+) tautog (Tautoga onitis [L.]) and cunner (Tautogolabrus adspersus [Walbaum]) in a southern New Jersey estuary. J. Exp. Mar. Biol. Ecol. 327:22-35. Crossref

Auster, P. J., R. J. Malatesta, and S. C. LaRosa.

1995. Patterns of microhabitat utilization by mobile megafauna on the southern New England (USA) continental shelf and slope. Mar. Ecol. Prog. Ser. 127:77-85. Crossref

Byron, C. J., and J. S. Link.

2010. Stability in the feeding ecology of four demersal fish predators in the US Northeast Shelf Large Marine Ecosystem. Mar. Ecol. Prog. Ser. 406:239-250. Crossref

Chin, A. T. M., J. Linke, M. Boudreau, M.-H. Thériault, S. C. Courtenay, R. Cormier, and M.-J. Fortin.

2018. Beta diversity changes in estuarine fish communities due to environmental change. Mar. Ecol. Prog. Ser. 603:161-173. Crossref

Clarke, K. R., P. J. Somerfield, and M. G. Chapman.

2006. On resemblance measures for ecological studies, including taxonomic dissimilarities and a zero-adjusted Bray-Curtis coefficient for denuded assemblages. J. Exp. Mar. Biol. Ecol. 330:55-80. Crossref

Collette, B. B., and G. Klein-MacPhee (eds.). 2002. Bigelow and Schroeder's fishes of the Gulf of Maine, 3rd ed., 748 p. Smithsonian Inst. Press, Washington, DC.

Collie, J. S., A. D. Wood, and H. P. Jeffries.

2008. Long-term shifts in the species composition of a coastal fish community. Can. J. Fish. Aquat. Sci. 65:13521365. Crossref

Crosby, S. C., N. L. Cantatore, L. M. Smith, J. R. Cooper, P. J. Fraboni, and R. B. Harris.

2018. Three decades of change in demersal fish and water quality in a Long Island Sound embayment. Estuar. Coasts 41:2135-2145. Crossref

Diaz, R. J., G. R. Cutter, and K. W. Able.

2003. The importance of physical and biogenic structure to juvenile fishes on the shallow inner continental shelf. Estuaries 26:12-20. Crossref

Drohan, A. F., J. P. Manderson, and D. B. Packer.

2007. Essential fish habitat source document: black sea bass, Centropristis striata, life history and habitat characteristics, 2nd ed. NOAA Tech. Memo. NMFS-NE-200, 68 p.

Grabowski, J. H., A. R. Hughes, D. L. Kimbro, and M. A. Dolan. 2005. How habitat setting influences restored oyster reef communities. Ecology 86:1926-1935. Crossref

Hare, J. A., W. E. Morrison, M. W. Nelson, M. M. Stachura, E. J. Teeters, R. B. Griffis, M. A. Alexander, J. D. Scott, L. Alade, R. J. Bell, et al.

2016. A vulnerability assessment of fish and invertebrates to climate change on the northeast U.S. continental shelf. PLoS ONE 11(2):e0146756. Crossref

Howell, P., and P. J. Auster.

2012. Phase shift in an estuarine finfish community associated with warming temperatures. Mar. Coast. Fish. 4:481495. Crossref 
Lewis, D. W., and D. McConchie.

1994. Analytical sedimentology, 197 p. Chapman \& Hall, New York.

Mercaldo-Allen, R., R. Goldberg, P. E. Clark, and C. A. Kuropat. 2011. Observations of juvenile lobsters, Homarus americanus, on a rock-reef in Long Island Sound. Northeast. Nat. 18:45-60. Crossref

Nye, J. A., J. S. Link, J. A. Hare, and W. J. Overholtz.

2009. Changing spatial distribution of fish stocks in relation to climate and population size on the northeast United States continental shelf. Mar. Ecol. Prog. Ser. 393:111-129. Crossref

Olla, B. L., A. J. Bejda, and A. D. Martin.

1979. Seasonal dispersal and habitat selection of cunner, Tautogolabrus adspersus, and young tautog, Tautoga onitis, in Fire Island Inlet, Long Island, New York. Fish. Bull. 77:255-261.

Peters, D. S., and F. A. Cross.

1992. What is coastal fish habitat? In Stemming the tide of coastal fish habitat loss: proceedings of a symposium on conservation of coastal fish habitat; Baltimore, MD, 7-9 May 1991 (R. H. Stroud, ed.), p. 17-22. Natl. Coalition Mar. Conserv., Savannah, GA.

Poppe, L. J., H. J. Knebel, Z. J. Mlodzinska, M. E. Hastings, and

B. A. Seekins.

2000. Distribution of surficial sediment in Long Island Sound and adjacent waters: texture and total organic carbon. J. Coast. Res. 16:567-574.

Rice, E., H. G. Dam, and G. Stewart.

2015. Impact of climate change on estuarine zooplankton: surface water warming in Long Island Sound is associated with changes in copepod size and community structure. Estuar. Coasts 38:13-23. Crossref

Rijnsdorp, A. D., M. A. Peck, G. H. Engelhard, C. Möllmann, and

J. K. Pinnegar.

2009. Resolving the effect of climate change on fish populations. ICES J. Mar. Sci. 66:1570-1583. Crossref

Rose, G. A.

2005. On distributional responses of North Atlantic fish to climate change. ICES J. Mar. Sci. 62:1360-1374. Crossref

Roseman, E. F., C. A. Tomichek, T. Maynard, and J. A. Burton. 2005. Relative abundance, age, growth, and fecundity of grubby Myoxocephalus aenaeus in Niantic River and
Niantic Bay, Long Island Sound. J. Sea Res. 53:309-318. Crossref

Scharf, F. S., J. P. Manderson, and M. C. Fabrizio.

2006. The effects of seafloor habitat complexity on survival of juvenile fishes: species-specific interactions with structural refuge. J. Exp. Mar. Biol. Ecol. 335:167-176. Crossref

Sedberry, G. R.

1988. Food and feeding of black sea bass, Centropristis striata, in live bottom habitats in the South Atlantic Bight. J. Elisha Mitchell Sci. Soc. 104:35-50.

Shorty, J. T., and D. P. Gannon.

2013. Habitat selection by the rock gunnel, Pholis gunnellus L. (Pholidea). Northeast. Nat. 20:155-170. Crossref

Snyder, J. T., M. M. Whitney, H. G. Dam, M. W. Jacobs, and H. Baumann.

2019. Citizen science observations reveal rapid, multidecadal ecosystem changes in eastern Long Island Sound. Mar. Environ. Res. 146:80-88. Crossref

Staniec, A., and P. Vlahos.

2017. Timescales for determining temperature and dissolved oxygen trends in the Long Island Sound (LIS) estuary. Cont. Shelf Res. 151:1-7. Crossref

Steimle, F. W., and C. Zetlin.

2000. Reef habitats in the Middle Atlantic Bight: abundance, distribution, associated biological communities, and fishery resource use. Mar. Fish. Rev. 62(2):24-42.

Tallman, J. C., and G. E. Forrester.

2007. Oyster grow-out cages function as artificial reefs for temperate fishes. Trans. Am. Fish. Soc. 136:790-799. Crossref

Tupper, M., and R. G. Boutilier.

1997. Effects of habitat on settlement, growth, predation risk and survival of a temperate reef fish. Mar. Ecol. Prog. Ser. 151:225-236.

Walsh, H. J., D. E. Richardson, K. E. Marancik, and J. A. Hare.

2015. Long-term changes in the distributions of larval and adult fish in the northeast U.S. shelf ecosystem. PLoS ONE 10(9):e0137382. Crossref

Wilcox, R. R.

2017. Understanding and applying basic statistical methods using R, 504 p. John Wiley \& Sons, Hoboken, NJ. 